\title{
Tromboelastografi - nyttig når det blør?
}

\author{
Blodprodukter er en begrenset ressurs. Flere studier har vist at bruk \\ av tromboelastografi (TEG) kan redusere behovet for blodtransfusjoner. \\ Analysen kan brukes i akuttsituasjoner hos pasienter med massive \\ blødninger for å veilede transfusjonsbehandlingen. Bruk av trombe- \\ lastografi kan spille en viktig rolle ved å gi en mer målrettet transfu- \\ sjonsbehandling.
}

Tromboelastografi (TEG) er en metode som gir et helhetsbilde av de viskoelastiske egenskapene til koagelet under hele koagulasjonsprosessen, helt fra den første danningen av fibrin til destruksjonen av koagelet. Metoden ble først tatt i bruk i 1940, hovedsakelig ved levertransplantasjoner (1). Etter hvert er bruksområdet utvidet, og metoden anvendes nå ved blant annet hjertekirurgi, massive blødninger ved kirurgi, traumer og obstetriske blødninger samt ved sepsis og påvisning av tilstander med hypo- og hyperkoagulabilitet (2). I mange kliniske tilfeller er koagulasjonsstatus hos pasienten uklar. Tromboelastografi gir et unikt her-og-nåbilde av pasientens koagulasjonssystem og kan dermed bidra til å skreddersy behandling med blodprodukter.

Gjennom samarbeid mellom anestesiavdelingen, som står for transfusjonsbehandlin-

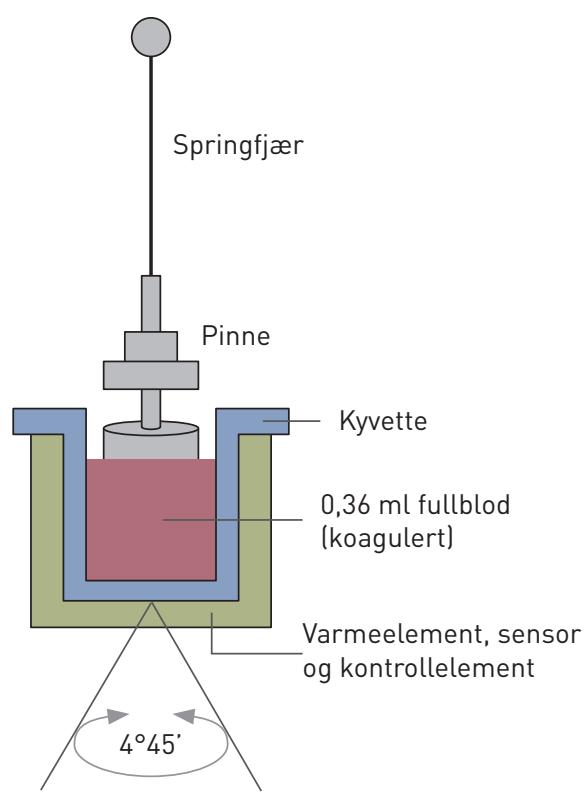

Figur 1 Kyvetten roterer blodet med en bestemt vinkel. Når koagulasjonen starter, vil motstanden i blodprøven registreres ved hjelp av en sensor koblet til en stålpinne. Den blir fremstilt grafisk i form av en kurve (fig 2, fig ). Basert på materiale fra Haemonetics, gjengitt med tillatelse gen, og avdeling for immunologi og transfusjonsmedisin har vi fătt god innsikt $\mathrm{i}$ bruken og nytten av denne metoden. Som representanter for disse to fagområdene ønsker vi å gi en kort introduksjon til analysemetoden, hva den kan brukes til og hvorfor vi mener den er nyttig $\mathrm{i}$ vår kliniske hverdag.

Det finnes flere instrumenter som er basert på tilsvarende prinsipper som tromboelastografi, som for eksempel rotasjonstromboelastometri (RoTEM). Metodene er teknisk sett noe forskjellige, men er hovedsakelig basert på samme prinsippet. Begge gir et helhetsbilde av de viskoelastiske egenskapene ved et koagel.

I denne artikkelen vil vi konsentrere oss om tromboelastografi, siden dette er metoden som brukes ved St. Olavs hospital.

\section{Analysemetoden}

Den cellebaserte koagulasjonsmodellen som ble lansert i 2001, ga en bedre forståelse av den viktige rollen blodcellene spiller i koagulasjonsprosessen (3). Tromboelastografianalysen utføres i fullblod. Det anses som en fordel - de vanlige koagulasjonstestene (APTT, INR, fibrinogen) utføres i plasma og måler derfor ikke det cellulære bidraget i koagulasjonen.

Analysen er rask og enkel å utføre, men krever standardiserte forhold, jevnlige kvalitetskontroller og daglig kalibrering. Dette er grunnen til at tromboelastografiinstrumentene ved St. Olavs hospital er plassert på Blodbanken, ikke ved operasjonsstuene, og at analysen utføres av bioingeniører.

I en tromboelastografianalyse bruker man en sitratblodprøve som tilsettes i en kyvette (fig 1). Analysen må utføres innen to timer etter prøvetaking. En tynn stålpinne roterer i kyvetten, slik at blodprøven, som er tilsatt aktivatoren kaolin, vil begynne å koagulere. Stålpinnen har en detektor som måler koagelets viskoelastiske egenskaper etter hvert som det dannes. Prosessen omgjøres til en grafisk kurve, der de ulike variablene representerer de ulike trinnene i koagulasjonsprosessen. Ved å sammenligne kurvens fasong med en «normalkurve» vil man få informa-

\section{Aurora Espinosa}

aurora.espinosa@stolav.no

Avdeling for immunologi og transfusjonsmedisin St. Olavs hospital

\section{Marit Seim Ekeland}

Avdeling for anestesi

St. Olavs hospital

\section{HOVEDBUDSKAP}

Tromboelastografi kan spille en rolle ved monitorering av koagulasjonsstatus hos pasienter med store blødninger

Analysen kan bidra til en mer fornuftig bruk av blodprodukter og gi pasienten en bedre tilpasset transfusjonsbehandling

Det er behov for flere studier for å evaluere nytten av tromboelastografi i traumesammenheng 


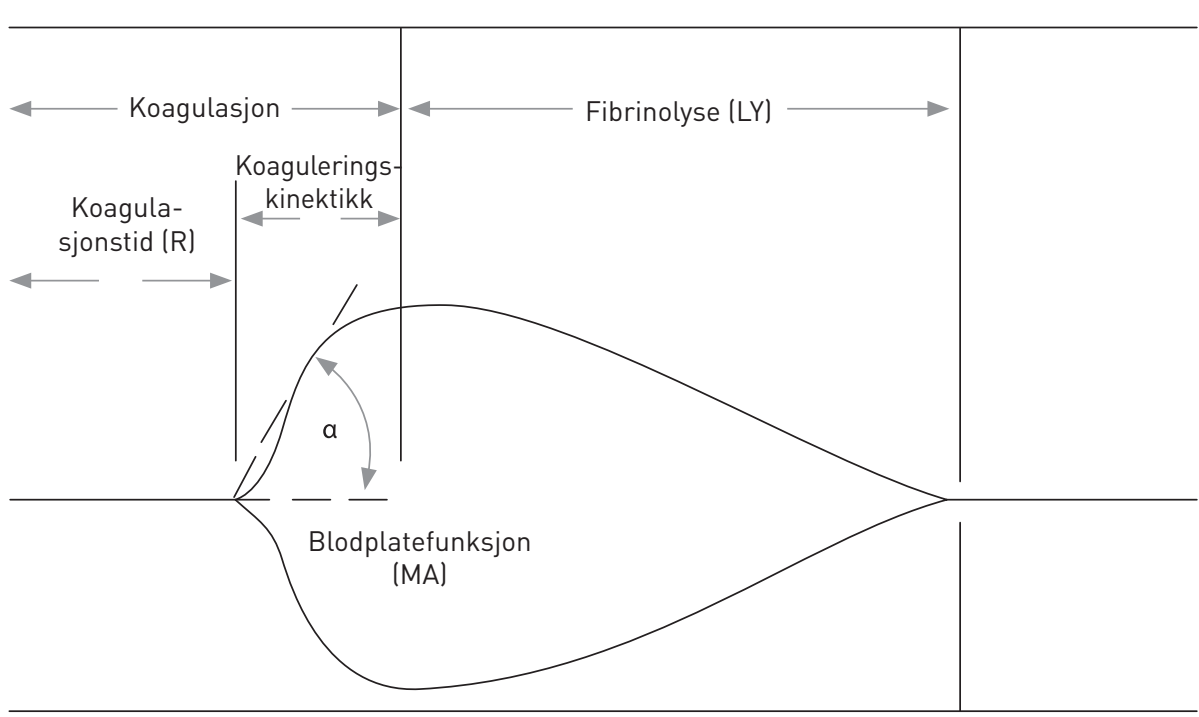

Figur 2 Variablene man skal vurdere i en tromboelastografikurve. Kurven har en dobbeltsidig fasong for å for enkle fortolkningen. Den gjenspeiler de to fasene i den hemostatiske prosessen. Den initiale fasen (koagulasjon) er avhengig av koagulasjonsfaktorer og blodplater. Variablene R, MA og alfavinkel gir informasjon om koagula sjonsfasen. Under fibrinolysen løses koagelet opp, representert av variabelen LY. I en sitratblodprøve vil fibrinolysen ikke vise seg så markert som på denne figuren, se figur 3. Det er kun ved veldig markert fibrinolyse at man kan se en slik markant nedgang på slutten av kurven

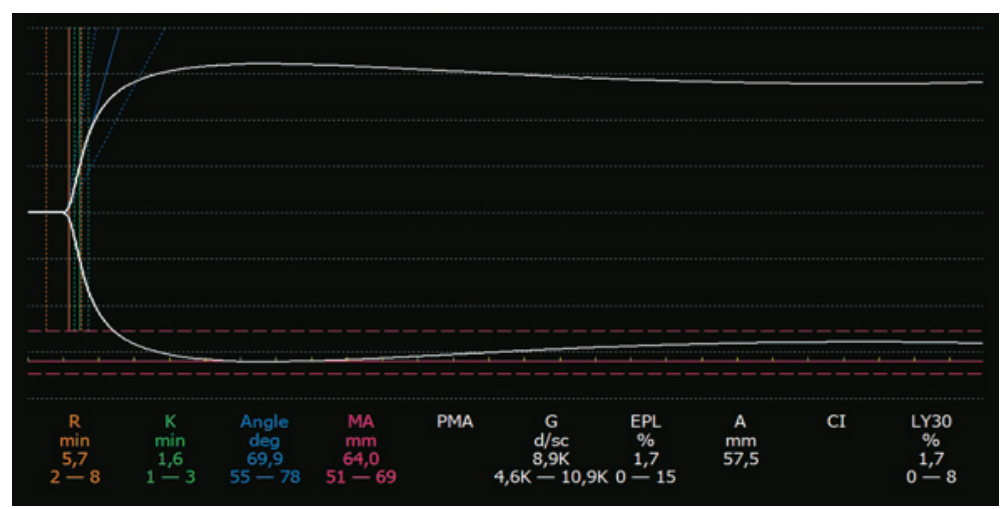

Figur 3 Eksempel på hvordan en normal kurve kan se ut. Alle variablene ligger innenfor referanseområdet. Disse vises under pasientens verdier for å forenkle tolkningen. Gjengitt med tillatelse av Haemoscope

sjon om pasientens koagulasjonsstatus (fig 2, fig 3, fig 4).

Når analysen er utført, sendes svarrapporten til rekvirenten, som dermed făr raskt tilgang til resultatene slik at eventuell blodtransfusjonsbehandling kan justeres etter den enkeltes pasients behov. Ved St. Olavs hospital jobbes det med å få på plass systemer for direkteoverføring av prøvesvaret i sanntid på operasjonsstuene (remote tromboelastography). Dette vil gi rekvirenten enda raskere tilgang til analysesvaret enn $\mathrm{i}$ dag.

Kostnaden ved analysen er liten i forhold til gevinsten av å spare blodprodukter (4). I tillegg kan den bidra til en mer målrettet transfusjonsterapi.

Det finnes fem ulike tromboelastografianalyser man kan benytte: standardtromboelastografi, hvor man benytter en sitratprøve som aktiveres ved hjelp av kaolin og kalsium- lenget R-verdi skal man vurdere transfusjon av plasma.

Maksimal amplitude (MA) er den maksimale avstanden mellom kurvelinjene. Den gjenspeiler trombocyttfunksjonen og styrken til koagelet som dannes. I tillegg har MA en fibrinogenkomponent, slik at man antar at ca. $80 \%$ av MA-verdien skyldes trombocyttfunksjonen og $20 \%$ skyldes fibrinogeninnholdet. En lav MA-verdi tyder på dårlig trombocyttfunksjon. Er det både lav MA-verdi og lav alfavinkel kan dette gi mistanke om lavt fibrinogennivå hos pasienten.

Alfavinkelen (dvs. hvor bratt kurven stiger) angir hvor raskt styrken til koagelet øker over tid. Denne variabelen korrelerer bra med fibrinogeninnholdet og kan brukes til å veilede fibrinogenterapi. Alfavinkelen bør tolkes i sammenheng med MA-verdien.

Med disse tre variablene får man mye informasjon om koagulasjonsstatus hos pasienten. Det er utarbeidet flere lokale transfusjonsalgoritmer basert på verdiene i trombelastografikurven for å veilede en eventuell transfusjonsterapi (5). Ved spesielle tilfeller med markert fibrinolyse kan LY 30\%-analyse også være av betydning. Den måler fibrinolysen i koagelet etter 30 minutter.

Tromboelastografikurven kan imidlertid være normal selv hos en blødende pasient. I slike situasjoner skal man utelukke eventuell behandling med platehemmere og/eller kirurgisk blødning.

\section{Når er tromboelastografi nyttig?}

Tromboelastografi kan være nyttig i flere kliniske situasjoner, som for eksempel ved store traumer med massive blødninger, blødninger ved hjertekirurgi og ved levertransplantasjoner. Ved postpartumblødninger eller uventet store blødninger i en elektiv situasjon kan man også ha nytte av å evaluere pasientens koagulasjonsstatus for å veilede videre transfusjonsbehandling (6). I flere studier har man i tillegg sett på nytten av tromboelastografi ved påvisning og reversering av de nye direktevirkende antikoagulasjonsmidlene (DOAK) (7). Disse anvendes av en stadig økende pasientgruppe der man fremdeles mangler gode analysemetoder for å evaluere pasientens koagulasjonsstatus.

Ved St. Olavs hospital har vi brukt tromboelastografi i klinisk sammenheng siden 2012. Det utføres ca. 200 analyser årlig, hovedsakelig i forbindelse med traumer. Personalet ved Blodbanken utfører analysen, som det også er mulig å rekvirere på døgnkontinuerlig basis. I en intern spørreundersøkelse utført i 2014 hos anestesilegene svarte $84 \%$ at de hadde brukt tromboelastografi i en eller flere situasjoner (ikke-publiserte data). Traumer ble imidlertid oppgitt som primærindikasjon for å rekvirere analysen i over halvparten av tilfellene.

Traumer er blant de ledende dødsårsakene 
i verden, og nær halvparten av traumerelaterte dødsfall relateres til blodtap (8). Behandling av massiv blødninger en stor utfordring for medisinsk personell. Sentralt i behandlingen står blødningskontroll og erstatning av blodtapet. Mye av dagens kunnskap om behandling av massive blødninger er kommet som resultat av væpnede konflikter i nyere tid.

Fra å behandle massive blødninger med store mengder klare væsker (krystalloider) skjedde det et paradigmeskifte i 1990-årene. Begrepet «begrenset væskeresuscitering» ble introdusert, og man ble etter hvert klar over den gunstige effekten av å gi fullblod tidlig hos sterkt traumatiserte pasienter (9). Dette gjorde at man begynte å gi blodprodukter (erytrocyttkonsentrat, trombocyttkonsentrat og plasma) i et $1: 1: 1$-forhold, slik at det skulle ligne fullblod (10). Det er dette som utgjør en «traumepakke» ved norske sykehus.

Mekanismen for koagulopatien som kan oppstå ved massiv blødning (trauma induced coagulopathy, TIC), og som er med på å opprettholde og eventuelt forverre blødningen, er fremdeles ikke godt forstått. I nyere forskning er det imidlertid påpekt hvor sentralt endotel og glykokalyks står i opprettholdelsen av normal hemostase (11). Målrettet transfusjonsterapi ved hjelp av instrumenter som tromboelastografi kan muligens redusere, eventuelt reversere, traumeindusert koagulopati (12).

Flere studier har vist at tromboelastografibaserte algoritmer kan bidra til å redusere blodforbruket, spesielt ved hjertekirurgi (13). Implementering av transfusjonsalgoritmer basert på instrumenter som tromboelastografi anbefales blant annet av den europeiske anestesiforeningen (ESA) (14). I København er det laget en lokal trombelastografibasert algoritme for behandling av pasienter med stor blødning, det såkalte Copenhagen Concept, der tromboelastografi er en av analysene som blir utført ved innkomst i akuttmottaket (15).

Ved traumer er ikke resultatene like entydige. Enkelte studier har vist at ved tidlig bruk av transfusjonspakker sammen med trombelastografi for å veilede transfusjonsbehandlingen har man klart å redusere mortaliteten hos pasienter med moderate traumer $(15,16)$ Man kan ikke utelukke at innføring av nye transfusjonsrutiner i seg selv kan føre til bedre overlevelse hos disse pasientene. Samtidig viser flere studier at det kan være sammenheng mellom enkelte tromboelastografivariabler og mortalitet $(17,18)$, noe som kan være nyttig ved valg av behandlingsalternativer. Det poengteres dog at det er behov for ytterligere forskning på dette feltet.

\section{Styrker og svakheter ved analysen}

Tromboelastografi har enkelte begrensninger. Analysen er relativt enkel å utføre, men
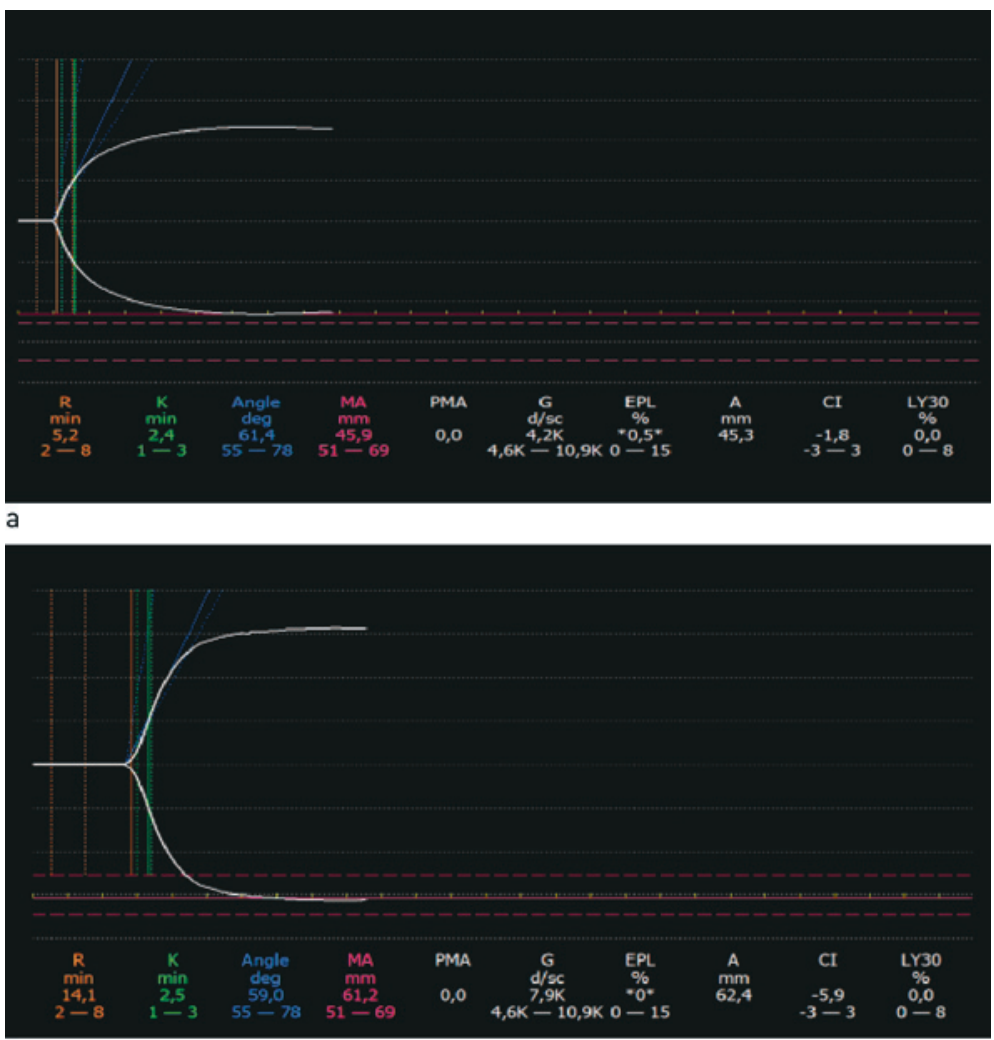

b

Figur 4 a) Platedysfunksjon. MA-verdien er på 45,9 mm, som er lavere enn referanseområdet (51-69 mm). Alfavinkelen på $61,4^{\circ}$ er innen referanseområdet (55-78\%). Lav MA-verdi med normal alfavinkel tyder mer på platedysfunksjon enn på fibrinogenmangel. Trombocytopeni, forbrukskoagulopati, fortynningseffekt ved massive transfusjoner uten platetransfusjon og tilstander som fører til blodplateaktivering, som bruk av hjertelunge-maskin, kan føre til lav MA-verdi. Lave MA-verdier hos blødende pasienter kan korrigeres ved hjelp av trombocytttransfusjon. b) Nedsatt konsentrasjon av koagulasjonsfaktorer. R-tiden er 14 minutter, noe som er utenfor normalområdet (maks. 8 min). De øvrige variablene er innefor referanseområdet. Fortynningseffekt ved massive transfusjoner uten transfusjon av plasma kan føre til forlenget $R$-verdi. En ekstremt forlenget $R$-verdi kan tyde på tilstedeværelse av heparin hos pasienten, noe som kan bekreftes ved hjelp av heparinasetrombelastografi. Forlenget $R$-tid kan korrigeres ved hjelp av plasmatransfusjon

krever standardiserte forhold. Dette gjør at den egner seg dårlig som pasientnært instrument, altså som et verktøy som kan brukes like ved pasientens seng. Analysen bør utføres av trent personell, og helst ved et laboratorium.

I den ovennevnte spørreundersøkelsen påpekte flere anestesileger at de ved store blødninger ofte fikk en normal tromboelastografikurve. Vi vil argumentere for at også en normal kurve gir nyttig informasjon, da man vet at pasientens koagulasjonssystem fungerer adekvat.

Ved hjelp av tromboelastografianalysen klarer man ikke å påvise effekten av platehemmere som blant annet klopidogrel og acetylsalisylsyre. Hos dem som får slike medikamenter, vil tromboelastografikurven være normal selv om de kan ha en koagulopati. For å kunne eliminere effekten av platehemmere på kurven kan man benytte en variant av tromboelastografi kalt blodplateanalyse (platelet mapping).
En annen begrensning er at normale referanseområder oppgitt av leverandøren er basert på verdiene hos enkelte friske blodgivere. Mange forskere har påpekt at det er viktig å etablere egne, lokale referanseområder for ulike pasientgrupper (19). St. Olavs Hospital har i den forbindelse sett på tromboelastografiverdier hos ikke-tranfusjonstrengende intensivpasienter, for å etablere normale referanseområder for denne pasientgruppen (20).

\section{Tromboelastografi i fremtiden}

Selv om nytten av tromboelastografi i traumesammenheng fremdeles ikke er entydig, pågår det flere store studier der man ser på denne problemstillingen. I en EU-ledet multisenterstudie (TACTIC) er seks store traumesentre i Europa inkludert, deriblant Oslo universitetssykehus. Man skal se på ulike behandlingsalgoritmer ved store blødninger og rollen ulike transfusjonsalgoritmer har på utfall og koagulasjon hos disse pasientene. Tromboelastografi/rotasjonstromboelastometri spil- 
ler en viktig rolle i dette forskningsprosjektet. Analysemetoden er viktig i forskningssammenheng og kan bidra til en bedre forståelse av de patologiske endringene i koagulasjonen som oppstår ved massiv blødning.

Videreutvikling av den nye og mer brukervennlige versjonen av tromboelastografi vil sannsynligvis gjøre testen enklere, mer pålitelig og raskere å utføre. Ved St. Olavs hospital har man inntil videre valgt å følge transfusjonsalgoritmer utarbeidet i København, men målet er å kunne etablere transfusjonsalgoritmer basert på eget pasientmateriale.

\section{Aurora Espinosa (f. 1968)}

er spesialist i immunologi og transfusjonsmedisin og seksjonsleder. Hun er medlem av den norske hemovigilans- og patient blood management-gruppen.

Forfatter har fylt ut ICMJE-skjemaet og oppgir ingen interessekonflikter.

\section{Marit Seim Ekeland (f. 1973)}

er spesialist i anestesiologi.

Forfatter har fylt ut ICMJE-skjemaet og oppgir ingen interessekonflikter.

\section{Litteratur}

1. Hartet $\mathrm{H}$. Blutgerinnungsstudien mit der thromboelastographie, einem neuen Untersuchungsverfahren. Klin Wochenschr 1948; 26: 557-83.

2. Hans GA, Besser MW. The place of viscoelastic testing in clinical practice. Br J Haematol 2016; 173: $37-48$.

3. Hoffman M. A cell-based model of coagulation and the role of factor VIla. Blood Rev 2003; 17 (suppl 1): S1-5.

4. Whiting $P, A l M$, Westwood $M$ et al. Viscoelastic point-of-care testing to assist with the diagnosis, management and monitoring of haemostasis: a systematic review and cost-effectiveness analysis. Health Technol Assess 2015; 19: 1-228, v-vi.

5. Ak K, Isbir CS, Tetik S et al. Thromboelastographybased transfusion algorithm reduces blood product use after elective CABG: a prospective randomized study. J Card Surg 2009; 24: 404-10.

6. Ekelund K, Hanke G. Stensballe J et al. Hemostatic resuscitation in postpartum hemorrhage - a supplement to surgery. Acta Obstet Gynecol Scand 2015; 94: 680-92.

7. Dias JD, Norem K, Doorneweerd DD et al. Use of Thromboelastography (TEG) for Detection of New Oral Anticoagulants. Arch Pathol Lab Med 2015; 139: $665-73$

8. Tien HC, Spencer F, Tremblay LN et al. Preventable deaths from hemorrhage at a level I Canadian trauma center. J Trauma 2007; 62: 142-6.

9. Stephens CT, Gumbert S, Holcomb JB. Traumaassociated bleeding: management of massive transfusion. Curr Opin Anaesthesiol 2016; 29 $250-5$

10. Holcomb JB, Zarzabal LA, Michalek JE et al. Increased platelet: RBC ratios are associated with improved survival after massive transfusion. J Trauma 2011; 71 (suppl 3): S318-28.

11. Ostrowski SR, Johansson PI. Endothelial glycocalyx degradation induces endogenous heparinization in patients with severe injury and early traumatic coagulopathy. J Trauma Acute Care Surg 2012; 73: 60-6.
12. Stensballe J, Ostrowski SR, Johansson PI. Viscoelastic guidance of resuscitation. Curr Opin Anaesthesiol 2014; 27: 212-8.

13. Westbrook AJ, Olsen J, Bailey M et al. Protocol based on thromboelastograph (TEG) out-performs physician preference using laboratory coagulation tests to guide blood replacement during and after cardiac surgery: a pilot study. Heart Lung Circ 2009; 18: 277-88

14. Kozek-Langenecker SA, Afshari A, Albaladejo P et al. Management of severe perioperative bleeding guidelines from the European Society of Anaesthesiology. Eur J Anaesthesiol 2013; 30: 270-382.

15. Johansson PI. Goal-directed hemostatic resuscitation for massively bleeding patients: the Copenhagen concept. Transfus Apheresis Sci 2010; 43: 401-5.

16. Johansson PI, Sørensen AM, Larsen CF et al. Low hemorrhage-related mortality in trauma patients in a Level I trauma center employing transfusion packages and early thromboelastography-directed hemostatic resuscitation with plasma and platelets. Transfusion 2013; 53: 3088-99.

17. Abdelfattah K, Cripps MW. Thromboelastography and Rotational Thromboelastometry use in trauma. Int J Surg 2016: 33 (Pt B): 196-201.

18. Carroll RC, Craft RM, Langdon RJ. Early evaluation of acute traumatic coagulopathy by thrombelastography. Transl Res 2009; 154: 34-9.

19. Scarpelini S, Rhind SG, Nascimento B et al. Normal range values for thromboelastography in healthy adult volunteers. Braz J Med Biol Res 2009; 42: 1210-7.

20. Holli Halset J, Hanssen SW, Espinosa A et al. Tromboelastography: variability and relation to conventional coagulation test in non-bleeding intensive care unit patients. BMC Anesthesiol 2015; 15: 28.

Mottatt 2.5. 2016, første revisjon innsendt 21.8.2016, godkjent 13.12. 2016. Redaktør: Ketil Slagstad. 